\title{
Beta Convergence Analysis on Transition Economies: 1991-2011
}

\author{
Asst. Prof. Dr. Ş. Mustafa Ersungur (Atatürk University, Turkey) \\ Ph.D. Candidate Aslı Cansın Doker (Erzincan University, Turkey) \\ Ph.D. Candidate Adem Türkmen (Erzincan University, Turkey)
}

\begin{abstract}
Owing to Solow's neo-classical the convergence hypothesis, which explains underdeveloped and developing countries grew faster than any of these developed countries have acknowledged that captures the level of per capita income, was added to the economic growth and development literature. Despite, theoretically there are two different approaches in convergence analysis; real and conditional, it cannot be said generalizing empirical results for both. Accordingly, 29 transition economies which tried to cross from the planned economic system into liberal economic system, is subjected to this study. Convergence have been analysed on transition economies between 1991 and 2011 using the growth rate of per capita income as variables by cross-sectional data analysis. In this study, additionally to real convergence, obtaining from the KOF index of economics, political and social integration and openness data were included the model as dummy variables for examining conditional convergence. Depending on empirical results on real and conditional convergence analysis, the convergence hypothesis is accepted. It is identified that Cambodia, Vietnam and China especially have caught up with faster growth comparing with other transition economies; however, those countries have shown weaker convergence than others. On the other hand, Kirghizstan and Tajikistan, which are known as mostly having the effects of transition recessions, have negative growth rates, and those countries have been diverging from other countries' growth performance. From findings obtained within conditional convergence, it is examined while political liberalisation and openness variables have been accepted significantly; the economic and social liberalization variables have no significant effect on convergence.
\end{abstract}

\section{Introduction}

It is an undeniable fact that the world income distribution between countries is in the hands of a minority called high-income countries. While there are various types of the classification for high-income and high-tradevolume countries, in this study the terminology used will be "developed countries". Thanks to both the needs of current colonialism and the colonization movement in the historical process, nowadays developed countries hold a large part of world trade through multinational companies in their hands. In this context, in terms of economies of less developed and developing countries were wondering, a question comes to capturing the developed countries of this group will be sturdy? This problem can be characterized in the literature as the development gap. This is basically the difference between the per capita income levels of low-income countries and highincome countries (Kaynak, 2007). In the 1950s, considering opinion on the closure of the development gap, the convergence hypothesis was put forward by Solow (Solow, 1956). With the hypothesis of convergence, Solow explained that advanced economies of the stationary state after reaching the rate of growth will slow down, pointing out the level of savings and population growth rate of developed countries, which are the same in less developed countries, marginal efficiency of capital is high and thus high growth rates will occur, thus these developed countries will catch the convergence hypothesis with tried to explain. In the literature of economic convergence there are three approaches which rejected convergence hypothesis. Firstly, efficient and effective technology can make technology leader countries richer. The second view, there is convergence in real life, but you can only take place between the countries' own use of modern technology. The last approach, poor or underdeveloped countries have potential to grow in long term but the gap between developed countries and them never closes. While all three approaches draw a pessimistic picture for under developed and developing countries, Barro (1991), Baumol (1986), and Delong (1988) in their work, as an argument of the countries' initial income levels, the dependent variable in per capita income growth in the average is models, establishing convergence with cross-sectional data have identified. These studies will be discussed in detail in the literature. Another approach for convergence analysis is that per capita income and long-term forecasts to examine the relationship between the series is stationary is interested in the time series approach. Key elements of this approach can be written as stationary series can converge to their long term average or return their trend; however, non-stationary series can be affected by shocks and those shocks can place permanently effects on their trend. Barron's horizontal cross-sectional modeling has been applied in this study.

\section{Literature Review}

Economic convergence has been discussed in many studies and the researcher's aim with using this approach is to determine real or conditional economic convergence on chosen 26 transition economies. The main question among international economics related to the convergence literature is how growth rate or trade may well affect convergence between countries. Over the post war period the world has been becoming relatively integrated 
through international trade. This integration has resulted to experience in their income per capita and also their purchasing power parity. The literature on economic convergence shows that international trade allows transferring knowledge, technology and also ideas to follower countries then this can press competitive market structure in follower countries. Competitive domestic market might well create positive pressure on production then speed of growth (Grossman et.al, 1991). Young (1991) stated another -pessimistic- approach for economic convergence in follower or poor countries is that with knowledge or ideas transfer can offer just little scope for growth or development in poor countries and he claims that little scope would become a trap for those. According to Krugman, owing to similarities on income levels, monopolistic competition and economies on scales can increase trade; moreover, spreading knowledge and technology transfers would be an indicator how the difference on income lowers between countries. Ban David (1993) shows that the timing of trade liberalisation identifies the relationship between income level and economic convergence. Helpman (1987) shows that learning process can create positive convergence on chosen 14 OECD countries with using bilateral trade data. Sahns and Warner(1995) claim that using dummy variables for determining social, politic and economic qualifications on economic convergence analysis gives more specific interpretations for countries and using as a term qualified and non-qualified classifications crate conditional converging countries groups. Dowrick Nguyen (1989) provided that initial rate of human capital signifies conditional economic convergence.

Critical body of convergence empirical studies on income convergence depends on another question which is countries converge to themselves on steady states despite their initial variables are less than differences in domestic steady state position (Durlauf et.al.,2005). Balwin et.al. (2003) shows that different stage of international trade liberalisation could make different convergence or divergence path through changing cross section. Barro (1991) states that political and economic openness are significant determinants for analysing economic convergence. Alesina et.al. (1992) indicates that some political phenomenon may strengthen the analysis which are economic and politic instability and democracy as a factor. Williamson (1993) argued that integration on global economy has existed since 1850 and he added that using grouping time series with two sub period has proved one convergence on restricted global trade between two world wars.

The convergence methodological literature provides a great number of approaches. In this part using this literature, features of convergence and techniques of convergence will be discussed respectively. There are two types of convergence which are Beta and Sigma convergence. Convergence analysis of the theoretical literature is quite broad methodological in outside of international economics. In this part, the features and techniques of convergence will be discussed. It is possible to divide convergence in two cases which are beta and sigma convergence respectively (Loewy, 1996). Baumol (1986) defined beta convergence among countries such that there is a negative correlation between the growth rates are described with using initial GDP and average growth rate (Hence we can speak of a beta convergence parameters for the start of the year must be less than zero. Sigma convergence, which is the second type of convergence, the standard distribution of income is continuously decreasing and sigma analysis subgroup analysis also means that regional (Zeren, 2011). For Sigma convergence, having Beta convergence for convergence but insufficient condition should be, not vice versa. Beta convergence is divided in itself is the first real convergence of the second conditional. Expected results from the convergence analysis of both types of beta parameter are negative and significant (Li et.al., 1999). So far, the studies that examined the horizontal section contain the results obtained with different techniques, but some of convergence can be mentioned in the literature gives them the ADF panel, ARDL and fuzzy model. Shibata et al. (2004) study of 64 African, Asian and Latin American countries made using panel data analysis of the sigma income convergence with trade liberalization have been detected. In the same study except African countries' groups has identified a beta convergence. Another important study, the Penn World data obtained using fuzzy modeling have been made to 88 countries. With this modeling is a positive relationship between openness and income has been identified (Stroomer et.al., 2003). Globalization is discussed in the context of the importance of technology diffusion, a relatively large openness in developing countries; the impact of globalization affects the speed of growth (Lutz, 2001).

\section{Data Set and Empirical Results}

In this study, GDP and average growth rate between 1991 and 2011 for chosen 29 transition economies has been determined as data determinants to analyze (Table 1). Barro and Sala-i Martin (1991) found a notation for conditional convergence with using chosen countries data sets which were initial per capita income levels and their long run per capita income levels to analyse rapid of growth convergence. In convergence analysis, with in formal notations, it is assumed that country $i$ have long run income per capita $y_{i}{ }^{*}$ and determined initial income level $\mathrm{y}_{\mathrm{i}}$. The rate of growth can be calculated from difference between $\mathrm{y}_{\mathrm{i}}{ }^{*}$ and $\mathrm{y}_{\mathrm{i}}$ this can be written such that;

$$
\dot{y}=\beta\left(y_{i}^{*}-y_{i}\right)
$$

The data used in the analysis from the Penn World Table 7.1 and 8.For the real convergence analysis; there are some calculations for the variables which are explained below in Table 2. 


\begin{tabular}{|c|c|c|}
\hline Countries & $\begin{array}{l}1991 \text { initial } \\
\text { GDP }\end{array}$ & $\begin{array}{c}\text { 1991-2011 } \\
\text { avarege growth } \\
\text { rate }\end{array}$ \\
\hline Albania & 2736.88 & 3.43 \\
\hline Armenia & 4489.21 & 2.50 \\
\hline Azerbaijan & 13436.19 & 2.48 \\
\hline Belarus & 11083.66 & 2.28 \\
\hline Bulgaria & 8802.31 & 2.73 \\
\hline Cambodia & 789.90 & 5.89 \\
\hline China & 2102.63 & 6.98 \\
\hline Croatia & 10283.48 & 1.26 \\
\hline Czech Republic & 15856.11 & 0.66 \\
\hline Estonia & 11751.40 & 2.49 \\
\hline Georgia & 7787.73 & 0.26 \\
\hline Hungary & 10211.32 & 1.84 \\
\hline Kazakhstan & 11306.98 & 1.01 \\
\hline Kyrgyzstan & 6573.63 & -3.84 \\
\hline Laos & 1232.25 & 3.67 \\
\hline Latvia & 10824.93 & 1.23 \\
\hline Lithuania & 9121.82 & 1.06 \\
\hline Macedonia & 4911.82 & 2.65 \\
\hline Moldova & 4119.68 & 0.27 \\
\hline Poland & 6748.90 & 4.70 \\
\hline Romania & 5627.61 & 3.75 \\
\hline Russia & 20057.46 & -0.06 \\
\hline Slovak Republic & 11328.07 & 1.65 \\
\hline Slovenia & 15223.16 & 1.29 \\
\hline Tajikistan & 5726.83 & -1.08 \\
\hline Turkmenistan & 8892.03 & 1.58 \\
\hline Ukraine & 8626.65 & 0.02 \\
\hline Uzbekistan & 4130.79 & 2.21 \\
\hline Vietnam & 1199.65 & 6.02 \\
\hline
\end{tabular}

Table 1: Data Set (Penn World Table 7.1 and 8)

\begin{tabular}{|l|l|}
\hline Rgdpo & Output-side real GDP at chained PPPs (in mil. 2005US\$) \\
\hline Pop & Population (in millions) \\
\hline
\end{tabular}

Table 2: The calculation methods of the data

In our model, Barron 's production is used instead of per capita national income calculated according to the total value of the real data obtained by dividing the population are used. Instead of real national income per capita spending power analysis will provide more accurate results to be obtained is preferred (Sach et.al., 1998).

Real convergence model is determined such that;

$$
\text { average growth rate }=\beta_{0}+\beta_{1} G D P_{\text {initial year }}
$$

In this study GDP for initial year which is 1991 and average growth rate in GDP per capita between 1991 and 2011 were used for modeling beta convergence analysis. The expectation from convergence analysis in econometric theory is suggested that having negative value of $\beta 1$ signify beta convergence. Moreover, the value of it can be interpreted the rapid of convergence. As a result of analysis for achieving the convergence hypothesis is that the negative value of expected cases but in this case $\beta_{1}$ convergence can be mentioned. Analysis results are shown below (Table 3).

\begin{tabular}{|l|l|l|l|}
\hline Variables & coefficients & t-Statistic & Prob. \\
\hline C & 3.828126 & 5.191535 & 0.0000 \\
\hline GDPPC1991 & -0.000222 & -2.808778 & 0.0091 \\
\hline
\end{tabular}

Table 3: The results of real convergence analysis

Real convergence model with theoretical expectations hypothesis of the beta coefficient is less than zero at the 0.01 significance level adopted and the existence of real convergence could be mentioned. Additionally, the rapid of convergence is 0.00022 which may well explain slow convergence for chosen countries. 


\subsection{Conditional Convergence Analysis}

The difference between conditional and real convergence analysis is usage of control variables in models. In this study, dummy variables out of the control variables determining the analysis has been made more specific. Each dummy variable is conditional constraint for chosen sample. Those dummy variables for 2013 data from the KOF index of political, social, economic globalization has benefited from the calculations in Table 4.

\begin{tabular}{|l|l|l|}
\hline Variables & Content Of Data & Mean \\
\hline d_eco & $\begin{array}{l}\text { Dummy for economic globalization: The KOF index was classified the degree of economic } \\
\text { globalization with using actual flows and restrictions on trade and capital. }\end{array}$ & 48.57 \\
\hline d_soc & $\begin{array}{l}\text { Dummy for social globalization : The KOF index was classified social globalization with } \\
\text { using three dimensions which are informational flows, personal contacts and cultural } \\
\text { proximity }\end{array}$ & 52.22 \\
\hline d_op & $\begin{array}{l}\text { Dummy for openness: Penn Word Table 7.1 calculated opennes with Openness at Current } \\
\text { Prices (\%) the Openness Index is the higher the index the larger the influence of trade on } \\
\text { domestic activities. }\end{array}$ & 92.907 \\
\hline d_over & $\begin{array}{l}\text { Dummy for overall globalization: it can be written as calutation of overall political, } \\
\text { economic and social globalization. }\end{array}$ & 51.131 \\
\hline d_pol & $\begin{array}{l}\text { Dummy for politic globalization: The KOF index was used political globalization to proxy } \\
\text { the degree of political globalization which includes the number of embassies in the country } \\
\text { and the number of membership on international organizations. }\end{array}$ & 56.704 \\
\hline
\end{tabular}

Table 4: The content detail of dummy variables

It also gives an opening for the other control variables which has benefited from the Penn World Table 8. This calculation method of the data sets is located in Appendix 1. Index of data between 1991 and 2011 were averaged and this average remaining countries under the " 0 " to countries with above average value of " 1 " is given. Dummy variables, the values in Table 5 are included in detail.

\begin{tabular}{|c|c|c|c|c|c|}
\hline Countries & $\begin{array}{l}\mathrm{d} \text { eco } \\
\text { mean }=48.57\end{array}$ & $\begin{array}{l}\mathrm{d} \text { soc } \\
\text { mean }=52.22\end{array}$ & $\begin{array}{l}\mathrm{d} \text { pol } \\
\text { mean }=56.704\end{array}$ & $\begin{array}{l}\mathrm{d} \text { genel } \\
\text { mean }=53.131\end{array}$ & $\begin{array}{l}\text { dop } \\
\text { mean=92.907 }\end{array}$ \\
\hline Albania & 0 & 0 & 1 & 0 & 0 \\
\hline Armenia & 1 & 0 & 0 & 0 & 0 \\
\hline Azerbaijan & 0 & 0 & 0 & 0 & 1 \\
\hline Belarus & 0 & 1 & 0 & 0 & 0 \\
\hline Bulgaria & 1 & 1 & 1 & 1 & 1 \\
\hline Cambodia & 1 & 0 & 0 & 0 & 0 \\
\hline China & 0 & 0 & 1 & 0 & 0 \\
\hline Croatia & 1 & 1 & 1 & 1 & 0 \\
\hline Czech Republic & 1 & 1 & 1 & 1 & 0 \\
\hline Estonia & 1 & 1 & 1 & 1 & 0 \\
\hline Georgia & 1 & 0 & 0 & 0 & 1 \\
\hline Hungary & 1 & 1 & 1 & 1 & 1 \\
\hline Kazakhstan & 1 & 0 & 0 & 0 & 1 \\
\hline Kyrgyzstan & 0 & 0 & 0 & 0 & 1 \\
\hline Laos & 0 & 0 & 0 & 0 & 1 \\
\hline Latvia & 1 & 1 & 0 & 1 & 1 \\
\hline Litvanya & 1 & 1 & 1 & 1 & 1 \\
\hline Macedonia & 0 & 1 & 0 & 0 & 0 \\
\hline Moldova & 1 & 1 & 0 & 0 & 1 \\
\hline Poland & 1 & 1 & 1 & 1 & 0 \\
\hline Romania & 0 & 1 & 1 & 1 & 1 \\
\hline Russia & 0 & 1 & 1 & 1 & 0 \\
\hline Slovak Republic & 1 & 1 & 1 & 1 & 1 \\
\hline Slovenia & 1 & 1 & 1 & 1 & 1 \\
\hline Tajikistan & 0 & 0 & 0 & 0 & 1 \\
\hline Turkmenistan & 0 & 0 & 0 & 0 & 1 \\
\hline Ukraine & 0 & 1 & 1 & 1 & 1 \\
\hline Uzbekistan & 0 & 0 & 0 & 0 & 1 \\
\hline Vietnam & 0 & 0 & 0 & 0 & 1 \\
\hline
\end{tabular}

Table 5: Dummy variables data set

The conditinal beta convergence is modelled such that; 
$y_{t}=\beta_{0}+\beta_{1} G D P_{\text {initial year }}+\beta_{2}$ Deco $+\beta_{3}$ Dsoc $+\beta_{4}$ Dgen $+\beta_{5}$ Dopen $+\beta_{5}$ Dpol

Results of the analysis are located below for 29 transition economies (Table 6).

\begin{tabular}{|l|l|l|l|}
\hline Variable & Coefficient & t-Statistic & Prob. \\
\hline C & 4.794765 & 4.173474 & 0.0004 \\
\hline GDPPC1991 & -0.00027 & -2.84112 & 0.0095 \\
\hline D_ECO & 0.023396 & 0.028218 & 0.9777 \\
\hline D_POL & 0.741761 & 0.535577 & 0.5976 \\
\hline D_SOC & -0.73185 & -0.56333 & 0.5789 \\
\hline D_OVER & 0.942263 & 0.453261 & 0.6548 \\
\hline D_OP & -1.50214 & -1.78215 & 0.0885 \\
\hline
\end{tabular}

Table 6: Results of conditional Beta convergence analysis

It can be said from above the exclusion of intercept dummy for openness, all dummies can rejected at 0.10 per cent. We also analyse all dummies one by one in this model after this, politic globalization and openness dummies are significant at 0.10 per cent (Table 7).

\begin{tabular}{|l|l|l|l|}
\hline Variable & Coefficient & t-Statistic & Prob. \\
\hline C & 3.600171 & 5.03483 & 0 \\
\hline GDPPC1991 & -0.000279 & -3.4289 & 0.002 \\
\hline D_POL & 1.42674 & 1.88596 & 0.0705 \\
\hline R-squared & 0.31925 & & \\
\hline
\end{tabular}

Table 7: Results of conditional Beta convergence analysis for political globalization dummy

\begin{tabular}{|l|l|l|l|}
\hline Variable & Coefficient & t-Statistic & Prob. \\
\hline C & 4.84607 & 5.88183 & 0.00000 \\
\hline GDPPC1991 & -0.00023 & -3.06794 & 0.00500 \\
\hline D_OP & -1.58469 & -2.24394 & 0.03360 \\
\hline R-squared & 0.351679 & & \\
\hline
\end{tabular}

Table 8: The conditional convergence results with openness dummy

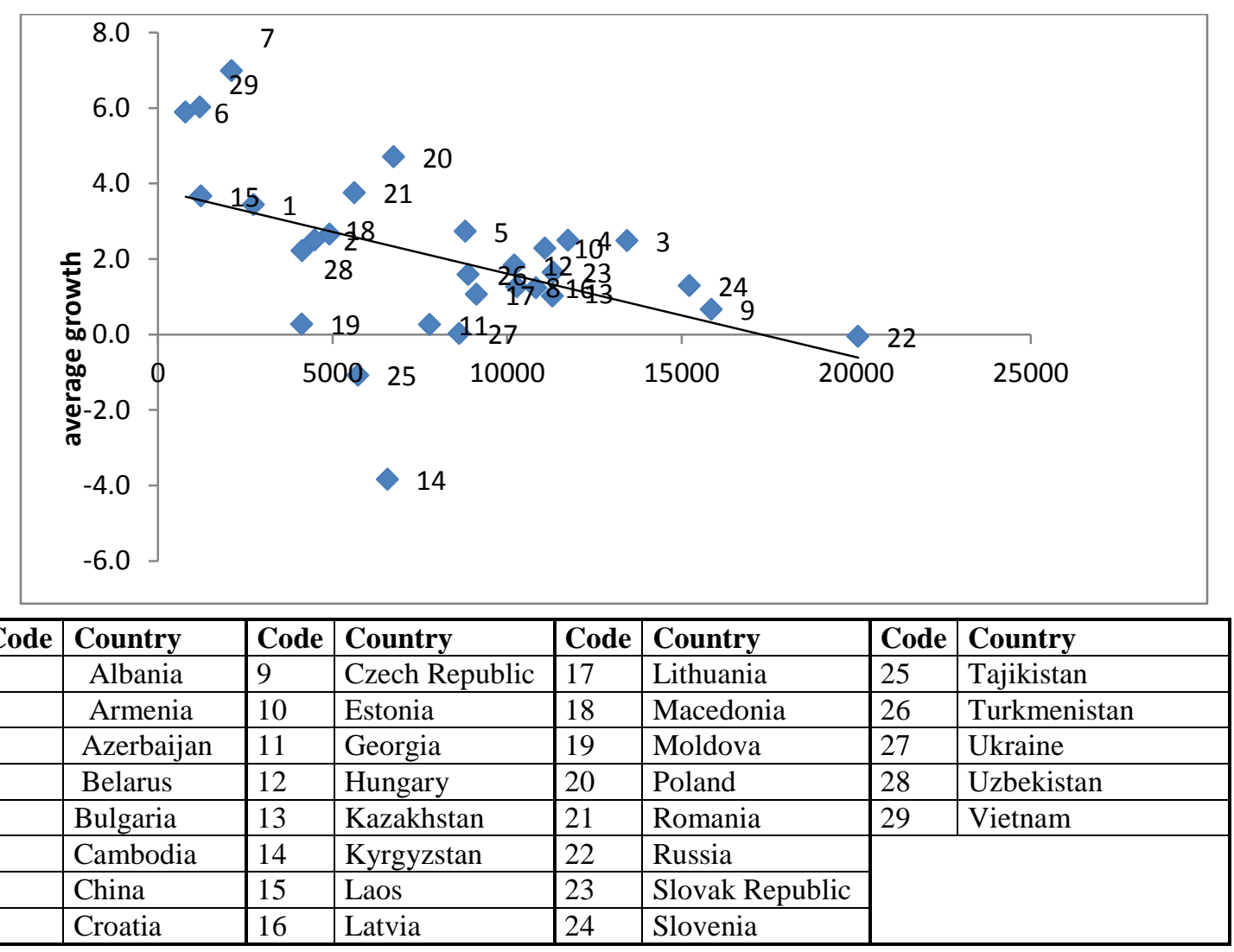

Table 9: Convergence scatter graph and countries codes 
According to this model at a significance level, political liberalization has taken place in the model significantly at the 0.05 level. Also for openness in other models in the model is significant at the 0.05 level of significance openings are located (Table 8).

Conditional convergence and real convergence analysis is significant, then scatter chart of the convergence of the country is seen more clearly (Table 8).

As seen in the graph Cambodia, Vietnam and China starting as low income countries, in the model because it requires the convergence of transition economies grew faster than in the general therefore have a divergent outlook. Kyrgyzstan and Tajikistan, the period referred to as having a negative growth rate as an average performance of other countries have turned away from convergence. Convergence performance of the countries on the chart shows a fairly regular distribution. Additionally, slope dummies are applied in conditional convergence analysis; however, none of dummies are significant at 0.10 levels.

\section{Conclusion}

In this study, real convergence and conditional convergence approach is applied on 29 transitional economies between 1991 and 2011 with using the average growth rate and the initial year 1991, which are provided from the income per capita, value of production calculation method of purchasing power parity. Analysis results showed that the chosen 29 transitional economies may well be mentioned for the real beta convergence. Additionally, dummy variables, which presented social, political and economic globalization and openness level for chosen countries, are statistically significant at the 0.10 level. The aim of using KOF index for conditional convergence is to see clearly the effects of political differences on convergence. It can be said that transitional economies not only have been converging to their average slowly and also political and social regulations effect the convergence. It can be seen from scatter chart of convergence that low income countries draw divergence trend during the period. Another important result is that European Union members which are Romania, Bulgaria, and Poland have remarkable positions with the convergence of growth rates. It is a crucial result for Tajikistan and Kyrgyzstan to have divergence with negative average growth rates. Moreover Cambodia, Vietnam and China show convergence, but in relatively high growth performances during the time period. For conditional convergence, only the political integration and openness variable was significant for Albania, Bulgaria, China, Croatia, Czech Republic, Estonia, Hungary, Lithuania, Poland, Romania, Russia, Slovakia, Slovenia, Ukraine. With having negative coefficient, political globalization dummy has negative pressure to convergence's speed or trend. On the other hand, with having positive coefficient, openness dummy has a positive impact on convergence. International economics theory expectations of transitional economies allow those results additionally for openness. As a result of this, it can be said that planned economic liberalization on the economies in transition might well result to convergence between countries supported by the results. Furthermore, it can be concluded that Tajikistan and Kyrgyzstan have negative values of the average growth rate within this aspect, it can be concluded that in the socialist economic system of production planning and in the liberalization process of adaptation caused to face serious economic crisis in those countries. Another remarkable point from this study, in Central Asia after the liberalization process experienced many political disputes adversely this affects growth in this area. This can be related with those economies grew faster than in the general therefore have a divergent outlook. It is clear that Middle Asian transition economies have some political critical issues; because of that, Kyrgyzstan and Tajikistan have turned away from convergence with negative growth rates. From the econometric analysis, convergence parameter, which expresses speed of convergence, is 0,00023 in other words, the speed of convergence is very low for chosen countries. In summary, there have been two weighted explanations from literature revision for slow convergence in transition economies. First of all, holding technological advantage for a country-especially transition economies in this case- helps to grow faster and richer because this can give them a technological leader position in their classification group. Secondly, economic growth and relatively convergence requires plausible regulations and institutions so transition economies need time to adapt and integrate those. From the findings it can be interpreted such that political institutions and regulations give an advantage for countries to converge. It is recommended that using dependent dummy variables to analyse political and social regulations effects on slope of convergence.

\section{References}

- Alan et.al, 2012. "Penn World Table Version 7.1", Center for International Comparisons of Production, Income and Prices at the University of Pennsylvania.

- Alesina and Nouriel, 1992. "Political Cycles in OECD Economies," Review of Economic Studies, Wiley Blackwell, vol. 59(4), pages 663-88, October.

- Ban , 1993.Equalizing Exchange: Trade Liberalization and Income Convergence. Quarterly Economics, Journal, no 108, pp.653-679.

- Barro, 1991. Covergence.J Political Economics, vol 100, pp.223-251. 
- Baumol, 1986. Productivity Of Growth, Convergence, And Welfare, American Economic Review,76(5),pp.1072-1085.

- Dreher et.al, 2008. Measuring Globalization - Gauging its Consequence, New York: Springer.

- Dowrick and Nguyen, 1989. OECD Comparitive Economic Growth 1950-1985: Catch up and Convergence, American Economic Review, no79, pp.1010-1030.

- Durlauf, 1999. The new emprics of economic growth Handbook of macroeconomic,. Elsevier, Amsterdam, pp235-308.

- Grossman et.al, 1995. "Economic Growth and The Environment”, Quarterly Journal of Economics, vol.110(2).

- Helpman, 1987. "Imperfect competition and international trade", Journal of Japanese International Trade Economics, pp.62-81.

- Kaynak, 2011. Kalkınma İktisadı, Gazi Kitabevi, Ankara.

- Krugman, 1994. Empirical Studies of Strategic Trade Policy. The University of Chicago Press, Chicago.

- Li and Papell, 1999. Convergence Of International Output Time Series Evidence For 16 OECD Countries, International Review of Economics \& Finance, 8(3), 267-280.

- $\quad$ Loewy and Papell, 1996. Are U.S. Regional Incomes Converging? Some Further Evidence, Journal of Monetary Economics, 38(3), 587-598.

- Lutz, 2001. "Globalisation, Convergence and the Case for Openness in Developing Countries: What Do We Learn from Open Economy Growth Theory and Empirics?”, CSGR Working Paper, Warwick, No. 72/01.

- $\quad$ Romer, Paul M.,(1986) “Increasing Returns And Long Run Growth”, Journal of Political Economy,1986,vol.94.pp.1002-1037.

- Sala-i-Martin X., (1996), "Regional Cohesion: Evidence and Theories of Regional Growth and Convergence", European Economic Review, 40, 1325-1352.

- $\quad$ Solow,R.M.(1956), A contribution to The theory of economic growth.Quarterly journal of economics,70,pp.65-94.

- Young, 1991. "Learning by Doing and Dynamic Effects of International Trade”, Quarterly Journal of Economics, vol. CVI.,no 2, pp.369-406.

- Williamson, 1993. "Economic Convergence: Placing Post famine Ireland in Comparitive Perspective", Discussion Paper No.1654, Harvard Institute of Economic Research. September 1993.

- Zdarek et.al., 2007, Real And Nominal Convergence The New Eu Member States-Actual State And Implications, Prague Economic Papers, No 3.

- Zeren and Yilanci, 2011. "Türkiye'de Bölgeler Arası Gelir Yakınsaması: Rassal Katsayılı Panel Veri Analizi Uygulamas1" Business and Economics Research Journal .vol2 pp. 143-151. 